JOTE Volume 3 Nomor 1 Tahun 2021 Halaman 59-64 JOURNAL ON TEACHER EDUCATION

Research \& Learning in Faculty of Education

\title{
PERSEPSI GURU TENTANG PENYEDERHANAAN KURIKULUM 2013 MASA PANDEMI COVID-19 DALAM MATA PELAJARAN SEJARAH TAHUN AJARAN 2020/2021 DI SMAN 1 SUNGAI RUMBAI DAN SMAN 2 SUNGAI RUMBAI
}

\author{
Zanelia Nafendani ${ }^{1}$, Liza Husnita ${ }^{2}$, Jaenam ${ }^{3}$ \\ Program Studi Pendidikan Sejarah, STKIP PGRI Sumatera Barat \\ Email : nzanelia990@gmail.com
}

\begin{abstract}
Abstrak
Tujuan dari penelitian ini untuk menguraikan Persepsi Guru Tentang Penyederhanaan Kurikulum 2013 Masa Pandemi Dalam Mata Pelajaran Sejarah Tahun Ajaran 2020/2021 di SMA N 1 Sungai Rumbai dan SMA N 2 Sungai Rumbai. Metode yang digunakan yaitu metode kualitatif. Teknik pengumpulan data yang dipakai yaitu: Observasi, Wawancara, Studi Dokumentasi. Teknik analisis data yang dilakukan dengan pengumpulan data, reduksi data, penyajian data, dan menarik kesimpulan. Hasil penelitian ditemukan bahwa Persepsi Guru Tentang Penyederhanaan Kurikulum 2013 Masa Pandemi Dalam Mata Pelajaran Sejarah Tahun Ajaran 2020/2021 di SMAN 1 Sungai Rumbai dan SMAN 2 Sungai Rumbai efektif digunakan pada masa pembelajaran pandemi. Hal ini didasari kecenderungan pandangan guru terhadap kurikulum darurat yang memiliki jam pelajaran dan pemaparan materi yang dikurangi sehingga dapat memudahkan peserta didik dan guru dalam kegiatan pembelajaran dimasa pandemi.
\end{abstract}

Kata Kunci: Persepsi Guru, Kurikulum 2013, Covid-19

\section{Abstract}

The purpose of this study was to describe Teacher Perceptions About Simplification of the 2013 Pandemic Curriculum in History Subjects for the 2020/2021 Academic Year at SMA N 1 Sungai Rumbai and SMA N 2 Sungai Rumbai. The method used is a qualitative method. Data collection techniques used are: Observation, Interview, Documentation Study. The data analysis technique was carried out by collecting data, reducing data, presenting data, and drawing conclusions. The results of the study found that Teacher Perceptions About Simplification of the 2013 Curriculum during the Pandemic Period in History Subjects for the 2020/2021 Academic Year at SMAN 1 Sungai Rumbai and SMAN 2 Sungai Rumbai effectively used during pandemic learning. This is based on the tendency of teachers to view the emergency curriculum which has reduced lesson hours and material exposure so that it can make it easier for students and teachers in learning activities during the pandemic.

Keywords: Teacher Perception, Curriculum 2013, Covid-19 


\section{PENDAHULUAN}

Dalam pendidikan suatu bangsa, pendidikan merupakan salah satu kebutuhan yang sangat penting dan tidak dapat dipisahkan dari kehidupan manusia. Pendidikan sebagai tolak ukur kemajuan bangsa berperan untuk membentuk individu yang beriman, bermoral dan berakhlak mulia serta berkualitas. Dalam hal ini peran guru sangat menentukan tercapainya tujuan pendidikan tersebut. Pendidikan ialah lembaga yang berperan penting dalam menciptakan Sumber Daya Manusia yang cerdas dan berkualitas. (Dewi, 2021)

Dalam pasal 1 Undang-undang Republik Indonesia Nomor 20 Tahun 2003 tentang Sistem Pendidikan Nasional menyebutkan bahwa: Pendidikan adalah usaha secara sadar dan terencana untuk mewujudkan suasana belajar dan proses pembelajaran agar peserta didik secara aktif mengembangkan potensi dirinya untuk memiliki kekuatan spiritual keagamaan, pengendalian diri, kepribadian, kecerdasan, akhlak mulia, serta keterampilan yang diperlukan dirinya, masyarakat, bangsa, negara (Pendidikan, Pendidikan, Dalam, \& Cipta, 2016).

Pelaksanaan pendidikan harus sesuai dengan tujuan yang diharapkan pada pasal selanjutnya pasal 3, Pendidikan nasional berfungsi mengembangkan kemampuan dan membentuk watak serta peradaban bangsa yang bermartabat dalam mencerdaskan kehidupan bangsa. Berarti pelaksanaan proses pendidikan diharapkan dapat membentuk manusia yang beriman dan bertakwa kepada Tuhan Yang Maha Esa. Pendidikan tidak hanya melahirkan seseorang yang ahli dalam bidang tertentu, namun termasuk juga bagaimana seseorang mampu membawa diri dalam lingkungan bermasyarakat, berbangsa dan bernegara sesuai dengan norma dan aturan yang berlaku. Pelaksanaan pendidikan tentu sangat masa pandemi covid-19 dengan sebelum masuknya virus ini sangat berbeda. Bermuara pada penyederhanaan kurikulum 2013 menjadi kurikulum darurat. (Pemikiran \& Volume, 2013)

Pendidikan merupakan usaha sadar dan terencana yang dilakukan baik secara formal maupun informal. Pendidikan formal biasanya dilakukan di dalam kelas atau yang di sebut dengan pembelajaran. Pembelajaran adalah kegiatan yang dilakukan oleh guru dan murid sehingga terjadi interaksi satu dengan yang lainnya. Kurikulum merupakan dasar serangkaian rencana untuk mencapai tujuan pembelajaran yang akan dilakukan. Kurikulum dalam masa tanggap darurat covid-19 memiliki sedikit perubahan yang dikeluarkan oleh Kementerian Pendidikan dan Kebudayaan Nomor 719/P/2020 dimana terdapat penyederhananaan kompetensi dasar yang diajarkan ke peserta didik sesuai dengan keadaan daerah. Kurikulum darurat dalam kondisi khusus ini tentu diterapkan oleh daerah terdampak Covid-19 untuk menjaga keselamatan dan kesehatan bersama. ("Pengaruh strategi pembelajaran," 2017)

Berdasarkan hasil observasi awal selama melakukan kegiatan PPLK di SMA N 1 Sungai Rumbai pada Desember 2020 dan Observasi awal di SMA N 2 Sungai Rumbai pada April 2021 ditemukan penerapan kurikulum 2013 pada masa pandemi guru melakukan pembelajaran dengan menerapkan kompetensi dasar yang telah disederhanakan pada silabus mata pelajaran sejarah Indonesia. Guru juga membuat perencanaan pembelajaran dengan saran pemerintah 
berupa penggunaan Rencana Pelaksanaan Pembelajaran satu lembar dimana pelaksanaan pembelajaran dengan waktu 35 menit dalam 1 jam pelajaran dan materi dalam pengajaran lebih sederhana dan tidak terlalu tajam dalam pembahasan materi pembelajarannya.

Guru memiliki peranan penting dalam penerapan peraturan dalam kondisi khusus ini. Kendati demikian, dalam kondisi khusus pun guru tetap seorang yang memiliki standar maupun kualifikasi guru yang tertuang dalam Peraturan Menteri Pendidikan Nasional Republik Indonesia Nomor 16 Tahun 2007 bahwa "Setiap guru wajib memenuhi kualifikasi akademik, kompetensi guru yang berlaku secara nasional". Pelaksanaan kurikulum darurat ini tentu dilaksanakan oleh guru mata pelajaran sejarah yang memiliki tanggapan maupun respon berbeda pada tiap guru mata pelajaran sejarah. Berkaitan dengan kondisi inilah penulis tertarik mengambil judul "Persepsi Guru Tentang Penyederhanaan Kurikulum 2013 Dalam Mata Pelajaran Sejarah Masa Pandemi Tahun Ajaran 2020/2021 Di SMAN 1 Sungai Rumbai dan SMAN 2 Sungai Rumbai".

Persepsi terdapat proses dalam diri untuk mengetahui dan mengevaluasi sejauh mana kita mengetahui orang lain. Disimpulkan bahwa persepsi ialah cara pandang individu terhadap sebuah situasi maupun penerapan sebuah peraturan yang menghasilkan penilaian terhadap sikap, perilaku dan tindakan seseorang. Persepsi merupakan sebuah cara pandang individu terhadap situasi maupun penerapan sebuah kebijakan atau aturan yang menghasilkan sebuah penilaian terhadap objek tertentu. Penyederhanaan kurikulum 2013 merupakan penyederhanaan muatan materi dalam kurikulum 2013 yang disebut sebagai kurikulum darurat. Adanya kurikulum darurat dikarenakan kondisi dimasa pandemi mengalami pembatasan ruang dan waktu. Hal itulah yang menyebabkan adanya kompetensi dasar yang dikurangi pada kurikulum 2013 dan menjadi kurikulum darurat. (Guru, Ibtidaiyah, \& Ata, 2020)

Persepsi dalam arti umum adalah pandangan seseorang terhadap sesuatu yang akan membuat respon bagaimana dan dengan apa seseorang akan bertindak. Persespi dapat didefinisikan sebagai proses pemberian makna, interpretasi dari stimuli dan sensasi yang diterima oleh individu, dan sangat dipengaruhi faktor faktor internal maupun ekternal masing-masing individu tersebut.(Shambodo, 2020)

Persepsi adalah anggapan berdasarkan pengalaman atau pengetahuan yang kadang berbeda antara satu orang dengan orang lain atau kadang berbeda dengan kondisi yang sebenarnya. mengetahui persepsi masyarakat terhadap suatu lembaga pendidikan merupakan upaya untuk melihat keinginan atau ekspektasi masyarakat terhadap lembaga tersebut. Perguruan tinggi sebagai lembaga sosial yang tumbuh dan berkembang dari dan untuk masyarakat tidak terlepas dari target dan sasaran yang dibutuhkan oleh masyarakat itu sendiri, sehingga perguruan tinggi yang memenuhi target dan sasaran tersebut akan selalu di cari oleh masyarakat.(Akbar, n.d.)

Persepsi memiliki beberapa faktor yang mempengaruhi antara lain objek yang dipersepsi, alata indera sebagai alat menerima stimulus, dan perhatian pada objek. Selain faktor yang mempengaruhi persepsi, ada tiga indikator dalam persepsi yaitu penyerapan terhadap sebuah objek diluar individu, pemahaman 
atau pengertian terhadap sebuah objek, dan penilaian atau evaluasi terhadap objek tertentu. Untuk melihat persepsi, atau mendapatkan sebuah persepsi atau pendapat tentu ada beberapa tahap untuk mendapatkannya sehingga barulah didapati sebuah persepsi objek tertentu (Akbar, n.d.).

Stimulus dan respon merupakan cara melihat klasik yang berhubungan dengan stimulus. Stimulus terkondisi ini tentu menghasilkan sebuah respon yang pasti. Setiap guru memiliki gaya berpikiran masing-masing dengan respon yang ditimbulkan stimulus berupa perubahan ketentuan pembelajaran dari pemerintah pusat dan perubahan kondisi pembelajaran. Teori ini memiliki rangsangan terhadap pembelajaran. Berakar dari teori behavioristic tentu teori stimulus respon berkaitan pada tingkahlaku seseorang. Teori ini dianggap relevan karena fokus penelitian pada pendapat, gagasan, maupun pikiran yang ada akibat sebuah perubahan atau kejadian yang terjadi memiliki dampak dalam kegiatan tertentu. Teori stimulus respon merupakan teori klasik erat kaitannya dengan komunikasi dimana dalam mendapati respon tentu adanya proses aksi dan barulah adanya sebuah reaksi yang disebut "persepsi".

Berdasarkan teori diatas alasan penulis mengambil teori stimulus respon Karena cocok dengan penulisan yaitu memcari informasi tentang penilaian atau tanggapan seseorang terhadap sebuah objek ataupun kebijakan. Penerimaan terhadap sebuah objek dan kemudian menanggapi atau merespon objek tersebut yang disini merupakan sebuah kebijakan pemerintah tentang penyederhanaan kurikulum 2013 dan dari sini melihat sebuah persepsi terhadap kebijakan tersebut.

\section{METODE}

Metode penelitian kualitatif deskriptif. Metode kualitatif memahami dan menafsirkan makna sebuah peristiwa interaksi tingkah laku manusia dalam situasi tertentu menurut pandangan peneliti sendiri. Menurut Sumanto, Penelitian deskriptif ialah sebuah penelitian yang diupayakan untuk mencandra atau mengamati permasalahan secara sistematis dan akurat mengenai fakta dan sifat objek tertentu. Penelitian deskriptif ditujukan untuk memaparkan dan menggambarkan dan memetakan fakta-fakta berdasarkan cara pandang atau kerangka berpikir tertentu. Metode ini berusaha menggambarkan dan menginterpretasi apa yang ada atau mengenai kondisi atau hubungan yang ada, pendapat yang sedang berkembang, proses yang sedang berlangsung, akibat atau efek yang terjadi, atau kecenderungan yang sedang berkembang.(Sidiq, 2019)

Metode kualitatif digunakan dengan tujuan memahami objek yang diteliti secara mendalam, mengembangkan pemahaman terhadap sebuah fenomena yang diamati. Berusaha memahami dan menafsirkan makna suatu peristiwa interaksi tingkah laku manusia dalam situasi tertentu menurut perspektif peneliti sendiri. Dilakukan dalam situasi yang wajar (natural setting). Metode kualitatif lebih berdasarkan pada sifat fenomenologis yang mengutamakan penghayatan (Imam Gunawan, 2015)

Penelitian ini menggunakan teknik pengumpulan data seperti observasi, wawancara, dan studi dokumentasi. Teknik observasi banyak digunakan dalam 
penelitian sejarah dan deskriptif karena melalui pengamatan gejala atau fenomena penelitian dapat diamati dari dekat untuk dikumpulkan dan dicatat. Wawancara yaitu mengadakan komunikasi secara langsung dengan pihak-pihak yang dijadikan sumber data yang penulis perlukan.(Anggianita \& Rizal, n.d.)

\section{HASIL PEMBAHASAN}

Persepsi merupakan sebuah cara pandang individu terhadap situasi maupun penerapan sebuah kebijakan atau aturan yang menghasilkan sebuah penilaian terhadap objek tertentu. Penyederhanaan kurikulum 2013 merupakan penyederhanaan muatan materi dalam kurikulum 2013 yang disebut sebagai kurikulum darurat. Adanya kurikulum darurat dikarenakan kondisi dimasa pandemi mengalami pembatasan ruang dan waktu. Hal itulah yang menyebabkan adanya kompetensi dasar yang dikurangi pada kurikulum 2013 dan menjadi kurikulum darurat. (Guru et al., 2020)

Persepsi dalam arti umum adalah pandangan seseorang terhadap sesuatu yang akan membuat respon bagaimana dan dengan apa seseorang akan bertindak. Persespi dapat didefinisikan sebagai proses pemberian makna, interpretasi dari stimuli dan sensasi yang diterima oleh individu, dan sangat dipengaruhi faktor faktor internal maupun ekternal masing-masing individu tersebut.(Shambodo, 2020)

Berdasarkan penelitian, tidak semua guru menilai bahwa penyederhanaan kurikulum 2013 ini cocok digunakan pada masa pandemi. Dua diantaranya menyatakan bahwa penyederhanaan kurikulum 2013 tidak cocok digunakan karena adanya beban guru dalam memenuhi standar media yang digunakan dalam pembelajaran daring maupun luring dan juga penyampaian materi yang disebabkan ketersediaan waktu yang tidak memadai. Penyampaian materi dengan menggunakam media video, guru dituntut agar kreatif dan juga bisa memaksimalkan media pembelajaran yang ada pada era digital. Tiga diantaranya menyampaikan cocok karena adanya pemanfaatan waktu dan materi yang sinkron dan mempermudah pelaksanaan pembelajaran dimasa pandemi ini. Beberapa materi yang dipangkas dianggap kurang essensial dalam mata pelajaran sejarah sehingga lebih baik ditiadakan sehingga waktu yang sedikit menjadi efektif. Dalam hal ini tentu guru mengikuti prosedur dimana kompetensi dasar yang dicantumkanlah yang diutamakan untuk disampaikan paparan materinya. Dan jika adanya keterkaitan dengan kompetensi dasar yang telah dihilangkan guru hanya menyampaikan secara ringkas dan tidak mendalam agar waktu yang ada cukup untuk digunakan menyampaikan materi inti dari kurikulum darurat saat ini.

\section{KESIMPULAN}

Berdasarkan uraian yang telah dijelaskan diatas dapat ditarik kesimpulan bahwa : Persepsi Guru Tentang Penyederhanaan Kurikulum 2013 Masa Pandemi Covid-19 Dalam Mata Pelajaran Sejarah Tahun Ajaran 2020/2021 di SMA N 1 Sungai Rumbai dan SMA N 2 Sungai Rumbai efektif atau cocok digunakan pada masa pembelajaran pandemi. Hal ini didasari kecenderungan pandangan guru terhadap kurikulum darurat yang memiliki waktu jam pelajaran 
dan pemaparan materi yang telah dikurangi sehingga dapat memudahkan peserta didik dan guru dalam kegiatan pembelajaran dimasa pandemi.

\section{DAFTAR PUSTAKA}

Akbar, R. F. (n.d.). MENENGAH PADA SEKOLAH TINGGI AGAMA A . Pendahuluan Perguruan tinggi merupakan satuan pendidikan yang menyelenggarakan pendidikan tinggi . Menurut jenisnya, perguruan tinggi dibagi menjadi dua yaitu : perguruan tinggi negeri , perguruan tinggi yang disele, 10(1), 189-210.

Anggianita, S., \& Rizal, M. S. (n.d.). Persepsi Guru terhadap Pembelajaran Daring di Sekolah Dasar Negeri 013 Kumantan, 1(2), 177-182.

Dewi, R. S. (2021). Peningkatkan Hasil Belajar Mata Pelajaran IPS Materi Ajar Makna Peninggalan-Peninggalan Sejarah yang Berskala Nasional di Indonesia dengan Menggunakan Media Gambar, 5, 2089-2098.

Guru, P., Ibtidaiyah, M., \& Ata, U. A. (2020). Persepsi Guru Madrasah Ibtidaiyah terhadap Pembelajaran Daring Selama Program Belajar dari Rumah ( BDR ) di Masa Pandemi COVID-19, XI(2).

Imam Gunawan. (2015). Metode Penelitian Kualitatif, 3.

Pemikiran, J., \& Volume, S. (2013). Jurnal Pemikiran Sosiologi Volume 2 No.1, Mei 2013, 2(1).

Pendidikan, K. D., Pendidikan, M., Dalam, N., \& Cipta, P. R. (2016). No Title, 2(1), 53-64.

Pengaruh strategi pembelajaran. (2017).

Shambodo, Y. (2020). Faktor Yang Mempengaruhi Persepsi Khalayak Mahasiswa Pendatang Ugm Terhadap Siaran Pawartos Ngayogyakarta Jogja TV, 1(2).

Sidiq. (2019). Metode Penelitian Kualitatif. 